\title{
Investigating the influence of conduit residues on polyurethane plates
}

\author{
Rachel Faverzani Magnago ${ }^{1 *}$, Nicolli Dayane Müller ${ }^{1}$, Mayara Martins ${ }^{1}$, Heloisa Regina Turatti Silva ${ }^{1}$, \\ Paola Egert ${ }^{1}$ and Luciano Silva ${ }^{2}$
}

\author{
${ }^{1}$ Una Produção, Construção e Agroindustria, Universidade do Sul de Santa Catarina - UNISUL, \\ Palhoça, SC, Brazil \\ ${ }^{2}$ Arranjo Promotor de Inovação em Nanotecnologia, Universidade Federal de Santa Catarina - UFSC, \\ Florianópolis, SC, Brazil \\ *rachel.magnago@unisul.br
}

\begin{abstract}
Converting waste into a product similar to the original one or into another useful product is to save energy, protect natural resources, and bring back to the production cycle what was discarded. In that direction, new polyurethane-based composites have been developed by incorporating 5\%, 10\%, 15\%, and 20\% PVC conduit discarded by the construction industry. The objective of this study was to investigate the interaction between the phases of waste incorporation and the effect upon the new material properties. The samples were produced by the polycondensation process. Microstructural analysis revealed a reduction in pore size across the polymer matrix. However, there were no changes in thermal insulation, water absorption, compressive strength, and burning rate tests and in the thermogravimetric analysis and differential scanning calorimetry. The results from this study showed that the replacement of raw material by waste did not affect its properties.
\end{abstract}

Keywords: conduit, insulation, polyurethane, residue, thermal.

\section{Introduction}

The supply chain of the construction industry is responsible for many positive impacts on the built environment, given that it enables the implementation of urban infrastructure and provides quality of life for its inhabitants. However, it consumes a significant amount of natural resources and generates tons of waste each year ${ }^{[1-4]}$.

Construction waste consists of various types of materials, such as concrete, mortar, wood, and plastic, accounting for about $60 \%$ of the entire residue collected each year in Brazil. In general, these materials are used for embankment, which can cause solubilization or leaching of certain harmful substances present in these materials. Furthermore, Mancini et al. ${ }^{[2,5-7]}$ claims that plastics have low biodegradability and occupy a large amount of space, decreasing the useful life of landfill areas. The effects of degradation can appear after 20-30 years ${ }^{[5,8]}$. Building companies are improving their construction techniques and optimizing proper waste disposal to meet the current Brazilian legislation (CONAMA Resolution No. 307) ${ }^{[9]}$. The environmental impact of building materials can be reduced signicantly by increasing the amount of recycled materials.

Polyvinyl chloride is a thermoplastic polymer widely used in construction works as electrical conduit pipes. PVC conduit can be embedded, buried, or apparent, typically used in electrical installations for buildings, with a rated voltage not exceeding $1000 \mathrm{~V}$ for alternating current, and frequency below $400 \mathrm{~Hz}$, or $1500 \mathrm{~V}$ for direct current. The conduit function is to protect and route electrical wiring in a building structure. It should withstand temperatures from $-5^{\circ} \mathrm{C}$ to $60{ }^{\circ} \mathrm{C}$ for 24 hours without showing any deformity, not allowing the passage of electric current above $100 \mathrm{~mA}$. PVC conduit was chosen as the focus of this research because the main properties of the material encompass thermal insulation, low flammability, and self-extinguishing flame ${ }^{[6,10-12]}$.

Polyurethane is a thermoplastic polymer often used in construction works due to its excellent performance as thermal and acoustic insulation ${ }^{[7,8,13-17]}$. The physico-chemical properties of polyurethane are important for that purpose ${ }^{[5]}$. The material has suitable mechanical strength to be used as thermal insulation in applications such as precast insulated sandwich wall panels, in ceiling lining or floors, and inside wood frame walls ${ }^{[18-21]}$. Singh ${ }^{[8]}$, however, warns that this is not suitable for surface coating and interior finishes in buildings because it is not resistant to fire. The ignition of polyurethane foams includes all gas-phase processes that occur between the fuel production step and the occurrence of a visible hot flame. The ignition of polyurethane foams occurs by the interdiffusion of the flammable gases with air. The basic physical and chemical aspects of gas-phase ignition reactions have been studied by several researchers ${ }^{[7,8,22]}$. Thus, the introduction of flame retardants is required in those situations ${ }^{[7,8,16,23]}$. Flame retardants are intended to inhibit or stop the polymer combustion process. Depending on their nature, they can act physically (by cooling, forming a dilution layer or fuel protection) or chemically (gas or condensed phase reaction). They can interfere with different processes involved in the polymer combustion (heating, pyrolysis, ignition, and propagation of thermal degradation $)^{[13,16,23]}$. 
There is a large number of flame-retardant additives, which are divided into halogenated and non-halogenated compounds $^{[3,13,16,23-28]}$. The halogenated flame retardants are more efficient than the non-halogenated composites, although they are more toxic during the burning process ${ }^{[23,26,27]}$.

Halogenated flame retardants are organic compounds containing chlorine or bromine (or fluorine, or iodine). When they decompose, they interfere with the combustion process, both in the gaseous combustion and in the condensed phase. However, fluorine- and iodine-based retardants are not commonly used because none of them interferes with the exact point of ignition of the combustion process $^{[22,23,25,26]}$.

In 2013, a tragedy of epic proportions was reported in the national and international media: the Kiss nightclub fire in the southern Brazilian city of Santa Maria ${ }^{[29]}$. This was not an isolated case, though. In 2003, there was a deadly Rhode Island nightclub fire in the United States as well. Several security failures were decisive for the former event, but it should be noted that polyurethane foam used for acoustic insulation has high flammability properties.

Flame retardants for polyurethane are generally utilized to retard ignition timing and reduce the burning rate and smoke formation. The type of flame retardant for PU depends on the application and rules that govern that application. Halogenated flame retardants are commonly used for rigid foams, and include tetrabromophthalic anhydride, aliphatic chlorine, tetrabromophthalate, and 2,3-dibromo-2-butene-1,4-diol ${ }^{[16,25,30]}$.

For that purpose, a polyurethane composite was developed with the incorporation of polyvinyl chloride (PVC) of flexible conduit residues ${ }^{[31]}$ from the construction industry. PVC was incorporated into the foam components by simple mechanical mixing at the compounding stage. This is still a relatively unexplored method, and this study is intended to contribute to analyze PVC compatibility with $\mathrm{PU}^{[32-40]}$. This paper presents an analysis of the conduit residue (PVC) incorporation into polyurethane to obtain plates, in order to investigate whether this material presents flammability reduction and improvement of thermal and mechanical properties.

\section{Materials and Methods}

\subsection{Preparation of the composites PU/PVC}

Formulated polyether polyol, and toluene diisocyanate reagents were purchased from Arinos company (Arinos Química, São Paulo, Brazil) to manufacture the composite. All reagents were used as received, and safety guidelines were followed.

Figure 1 exhibits a package of PVC conduit in yellow as marketed (Figure 1A). PVC conduit installation during construction generates residual cuts that are usually discarded. After collection, the residues were washed, dried in an oven
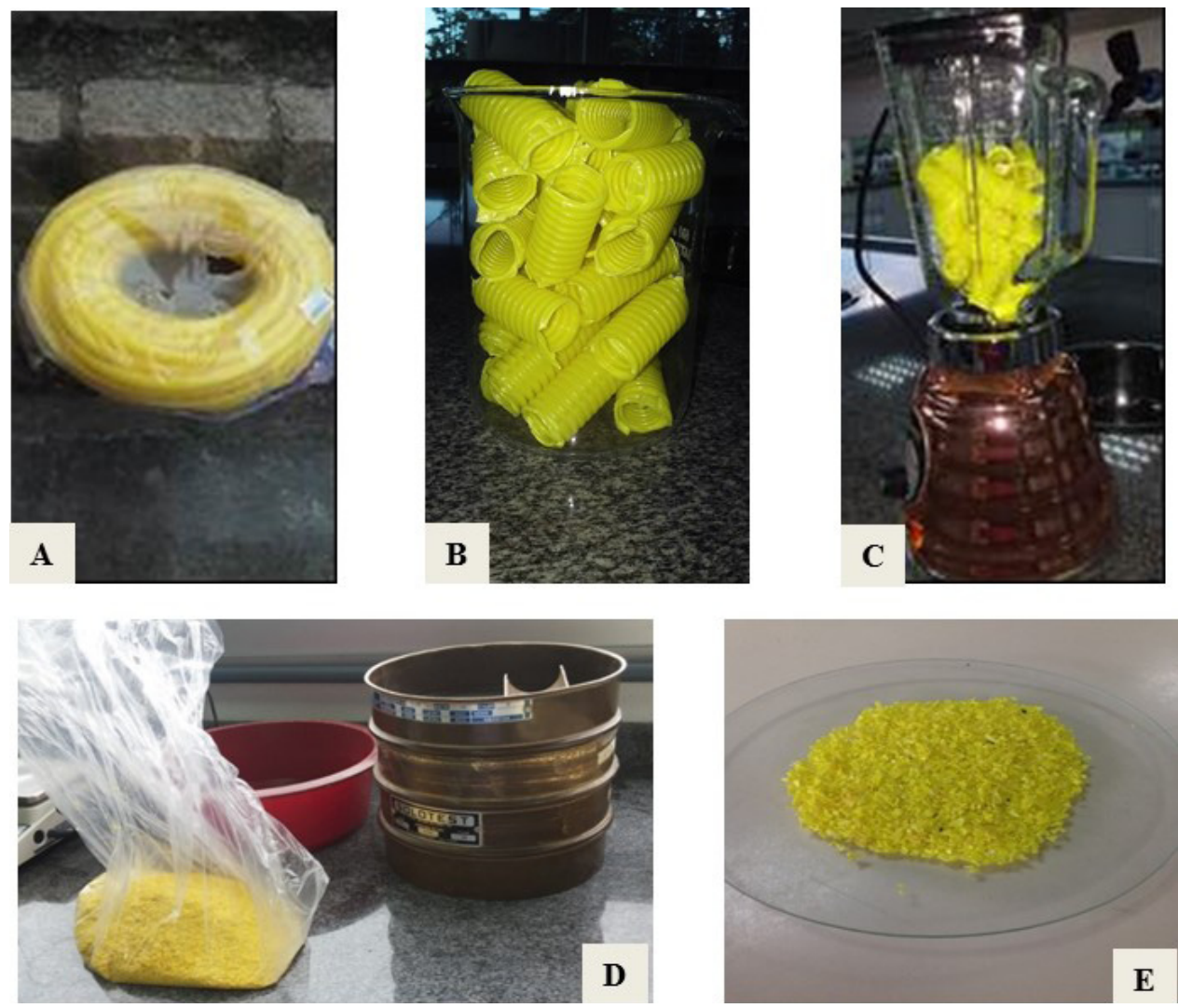

Figure 1. (A) Flexible PVC conduit; (B) pieces of conduit cuts; (C) pieces for grinding; (D) triturated conduit and sieves for particle size classification; (E) conduit powder with particle size less than $1.18 \mathrm{~mm}$. 
at $40{ }^{\circ} \mathrm{C}$ for 48 hours, and ground in a blender (Figure 1B) and classified by particle size (Figure 1C). A number 16 ASTM stainless steel sieve was used for the classification of grain sizes. The material used for the production of composites presented particle sizes passing a $1.18 \mathrm{~mm}$ sieve (Figure 1D) and Mw 108.511 (Mw/Mn 2.233).

Molecular mass distribution of the PU and PVC was estimated by size exclusion chromatography (SEC), using a GPC Viscotek VE2001 with an ultraviolet detector at the wavelength of $280 \mathrm{~nm}$ and bimodal exclusion columns PVDF. Samples weight was 0.01-0.02 g and tetrahydrofuran was used as an eluent. The calibration of columns was carried out with a polystyrene standard of the Mw 30,000 and polydispersity Mw/Mn 1.0. The model polyurethane used as a standard was synthesized from the same polyether polyol and the same toluene diisocyanate (component molar ratio was $1: 1.1$, Table 1 ).

Specimens with a mass percentage of $5 \%, 10 \%, 15 \%$, and $20 \%$ of PVC waste were prepared to substitute for polyurethane (polyol and isocyanate) with a total mass of $12.85 \mathrm{~g}$. PVC was incorporated into the foam components by simple mechanical mixing at the compounding stage. Table 1 shows the mass of the reagents used in each test.

The composites were obtained by mixing conduit residues (PVC) to formulated polyether polyol, and adding toluene diisocyanate. The mixture was stirred for $0.5 \mathrm{~min}$ and poured into a mold $0.05 \mathrm{~m}$ in diameter and $0.1 \mathrm{~m}$ height, cut in half vertically to facilitate demolding. A lid $0.05 \mathrm{~m}$ in diameter was used to close the molds. The specimens were demolded after 24 hours $^{[38,41,42]}$.

The curing time consisted in the reaction between hydroxyl (formulated polyether polyol) and isocyanate groups (isocyanate polymer), leading to the formation of a polymeric matrix

Table 1. Amounts of raw materials for the production of PU specimens and PU/PVC composites with $5 \%, 10 \%, 15 \%$, and $20 \%$ of PVC from conduit residues.

\begin{tabular}{cccc}
\hline & Poliol (g) & $\begin{array}{c}\text { Toluene } \\
\text { diisocyanate } \\
\mathbf{( g )}\end{array}$ & $\begin{array}{c}\text { PVC residues } \\
(\mathbf{g})\end{array}$ \\
\hline PU & 6.12 & 6.73 & - \\
PU/5PVC & 5.85 & 6.39 & 0.64 \\
PU/10PVC & 5.50 & 6.06 & 1.29 \\
PU/15PVC & 5.20 & 5.72 & 1.93 \\
PU/20PVC & 4.90 & 5.39 & 2.56 \\
\hline
\end{tabular}

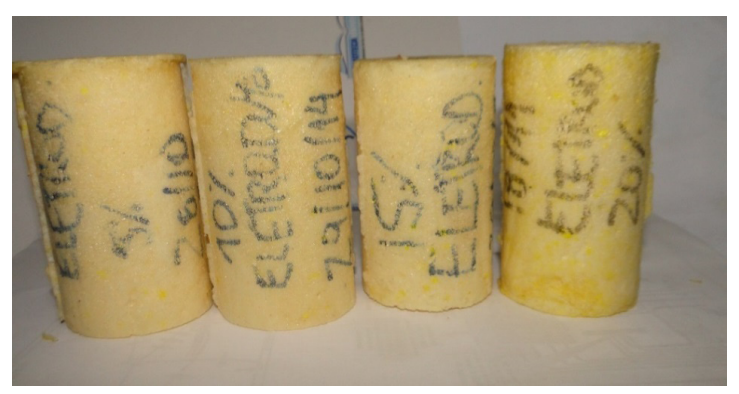

Figure 2. PU/PVC composites with $5 \%, 10 \%, 15 \%$, and $20 \%$ conduit.
(Mw 278 and Mw/Mn 1.133). The chemical reaction that occurs between isocyanate and polyol forms a chemical bond by urethane links (-O-CO-NH-), which forms polyurethane because of polycondensation ${ }^{[14,43,44]}$. Isocyanate worked as a crosslinking agent, promoting solidification of the mixture, thus the proportions of the reactants were maintained for all composites ${ }^{[21,22]}$. Immediately after adding the curing agent, the mixture viscosity was suitable for being poured into the molds. The incorporation of the conduit residue occurred in different proportions with mass reduction of the reagents at baseline, being incorporated into PU.

Figure 2 shows the PU/PVC composites with 5\%, $10 \%, 15 \%$, and $20 \%$ conduit. They had a uniform surface, good visual appearance, and showed no deformation after demolding.

\subsection{Scanning Electron Microscopy (SEM)}

The micrographs of PU and PU/PVC plates were obtained by scanning electron microscopy using a JEOL JSM-6390LV device, at a voltage of $15 \mathrm{kV}$, and the samples were fractured in liquid nitrogen.

\subsection{Water resistance test}

The procedure followed the gravimetric method recommended by the Standard Test Method for Water Absorption of Plastics D 570-98 ${ }^{[45]}$.

Initially, the samples were oven-dried at $50{ }^{\circ} \mathrm{C}$ for 24 hours. The dry material was weighed on a digital scale (Shimadzu BL-3200H) with a precision of $0.01 \mathrm{~g}$. Then, the samples were immersed in a distilled-water bath at $25^{\circ} \mathrm{C}$ for 24 hours. After that, they were removed and dried with paper towels and weighed again. The water absorption rate was obtained by the following formula:

$$
\mathrm{A}=\frac{\text { Msat }-\mathrm{Ms}}{\mathrm{Ms}} \times 100
$$

where: A: Water absorption (\%); $\mathrm{M}_{\text {sat: }}$ Mass of saturated sample (g); $\mathrm{M}_{\mathrm{s}:}$ Mass of dry sample $(\mathrm{g})$.

\subsection{Thermal insulation}

The insulation test consisted of a qualitative evaluation for comparison of heating curves between the PU and the developed materials. A specimen made from the composite containing an internal cavity was developed to perform the assay. This apparatus allowed placing a beaker inside with $10 \mathrm{ml}$ of previously cooled water, as shown in Figure 3. A heating curve for water was then provided by using a digital thermometer (Hanna HL2221) at 10-minute time intervals, up to a maximum time of 60 minutes.

\subsection{Mechanical compression strength}

Mechanical compressive strength tests followed the requirements of ASTM D695-15 ${ }^{[47]}$. The mechanical tests were carried out by compressing $5 \mathrm{kN}$ load cell in a universal testing equipment (EMIC DL-30000), according to the requirements of ASTM D-63890. In these tests, the specimens were subjected to pressure increments until the plastic deformation occurred, at room temperature. 


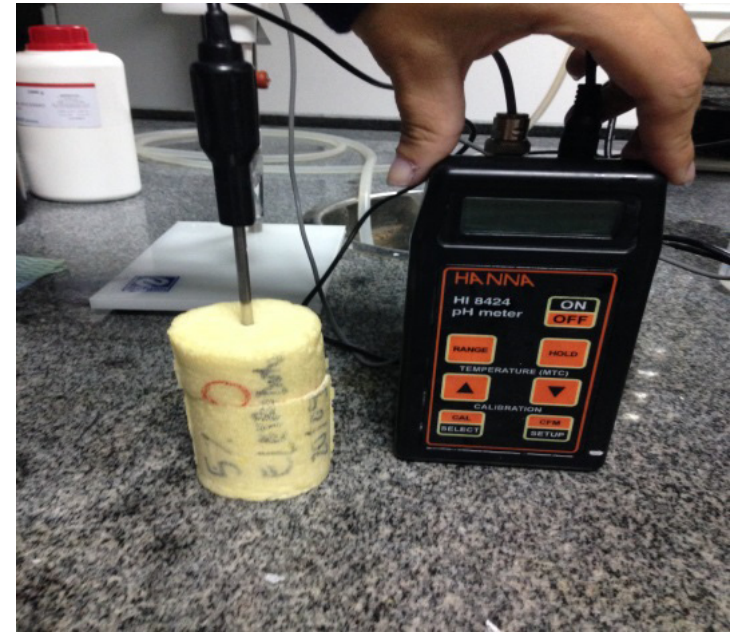

Figure 3. Tests run and molds used. Source: Tudo Sobre Plasticos $^{[46]}$.

\subsection{Differential Scanning Calorimetry (DSC)}

The analysis of differential scanning calorimetry was performed by using the Q2000 Thermal Analyst Instruments, Universal (TA Instruments). The temperature of the samples ranged from $-50{ }^{\circ} \mathrm{C}$ to $150{ }^{\circ} \mathrm{C}$, with heating-cooling rate of $5{ }^{\circ} \mathrm{C} \mathrm{min}-{ }^{1}$ under nitrogen atmosphere.

\subsection{Thermogravimetry}

Thermogravimetric analysis (TGA) of samples was performed under nitrogen atmosphere at a heating rate of $10{ }^{\circ} \mathrm{C} /$ min within a temperature range of $20^{\circ} \mathrm{C}$ to $900{ }^{\circ} \mathrm{C}$, using a TGA Q5000 (TA Instruments) device.

\subsection{Burning rate}

Tests to measuring the burning characteristics followed the requirements of NBR 9178:2015 ${ }^{[48]}$ and ASTM D3801. Five samples of the composite measuring $102 \mathrm{~mm}$ in width $\times 356 \mathrm{~mm}$ in length $\times 13 \mathrm{~mm}$ in thickness were used for the tests. Each sample was placed in contact with the flame, and measurements were made of the time it took for the material to combust, and the distance traveled by the flame along the board. Figure 4 shows a schemating drawing of the test.

\section{Results and Discussions}

\subsection{Scanning Electron Microscopy}

Scanning Electron Microscopy (SEM) analysis made it possible to evaluate the effect of incorporating conduit residues into the morphology of polyurethane foam. Figure 5 shows images of PU (5A and 5B) and images of PU containing $20 \%$ conduit residue ( $5 \mathrm{C}$ and $5 \mathrm{D}$ ). There is no certified or standard micrograph for PU foams, given that they vary with the type and percentage of their component ${ }^{[3,4,27,28,31,49]}$. Therefore, the PU sample used as reference was prepared under the same conditions of the composite.

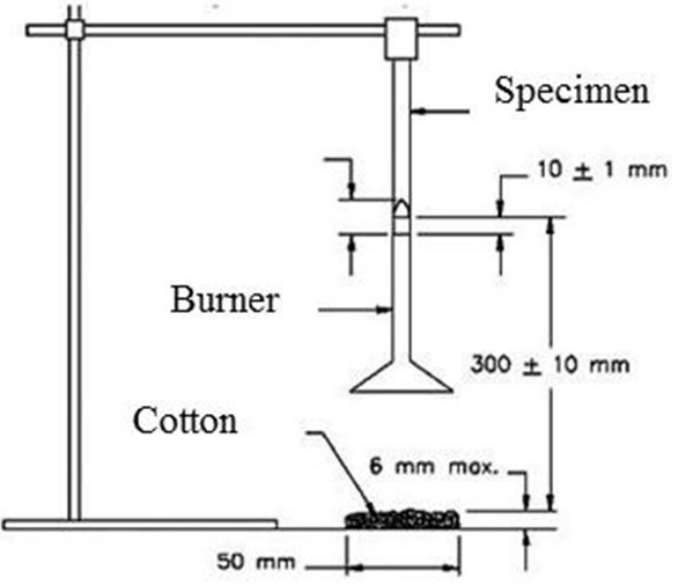

Figure 4. Schematic drawing for polyurethane combustion test.

Figure 5 images show that cryogenically fractured surfaces exhibited a closed-cell structure, probably due to the type of cross-link during the polymerization reaction, which helps reduce cell disruption during the expansion process. Both the PU (Figure 5A and 5B) and the PU/PVC composite (Figure 5C and 5D) had an approximately spherical shape. There was a PVC dispersion in PU, and the interaction between the polymers occured at the interfacial level. There were hard PVC particles in the PU foam, which led to foam contraction ${ }^{[31,49]}$. Cell growth was hampered by the incorporation of the conduit as it can be seen by comparing $5 \mathrm{~A}(\mathrm{PU})$ with $5 \mathrm{C}(\mathrm{PU} / \mathrm{PVC})$, at a 15 -fold magnification, and 5B (PU) with 5D (PU/PVC), at a 30-fold magnification. PU cells have a diameter of about $0.800 \mathrm{~mm}$ (Figure 5A), whereas PU/20PVC composite cells (Figure 5C) have a diameter of about $0.300 \mathrm{~mm}$, corresponding to an approximately 2.5 -fold reduction. PU has cell size around $0.800 \mathrm{~mm}(5 \mathrm{~A})$, whereas in the image $5 \mathrm{C}$ there are up to three cells in $0.800 \mathrm{~mm}$. The embedded $\mathrm{PVC}$ presented a maximum size of $1.18 \mathrm{~mm}$, and the size reduction of PU foam cells was higher in the composite containing $20 \%$ PVC.

There was good adhesion between PU and PVC resulting from intermolecular interactions between $\mathrm{Cl}$ groups (PVC) and $\mathrm{N}-\mathrm{H}$ groups $(\mathrm{PU})^{[50]}$, given that $\mathrm{PU}$ foam was observed in PVC particle on the fracture surface, as circled in Figures $5 \mathrm{C}$ and $5 \mathrm{D}$. Another indication of this interaction is that the images were obtained from the fracture surface, and there were no signs that the conduit was pulled out of the matrix at the time of the fracture. In fact, this homogeneity between conduit and matrix is essential for mechanical reinforcement ${ }^{[51]}$.

The presence of predominantly closed-cell structures prevented moisture absorption, blocked the passage of gases and vapors, and did not communicate with the external environment. These are important characteristics for materials to be used as thermal insulation ${ }^{[2,53]}$. This behavior was maintained for all prepared PU/PVC composites, regardless of the percentage of conduit residues (PVC) incorporated into PU. 

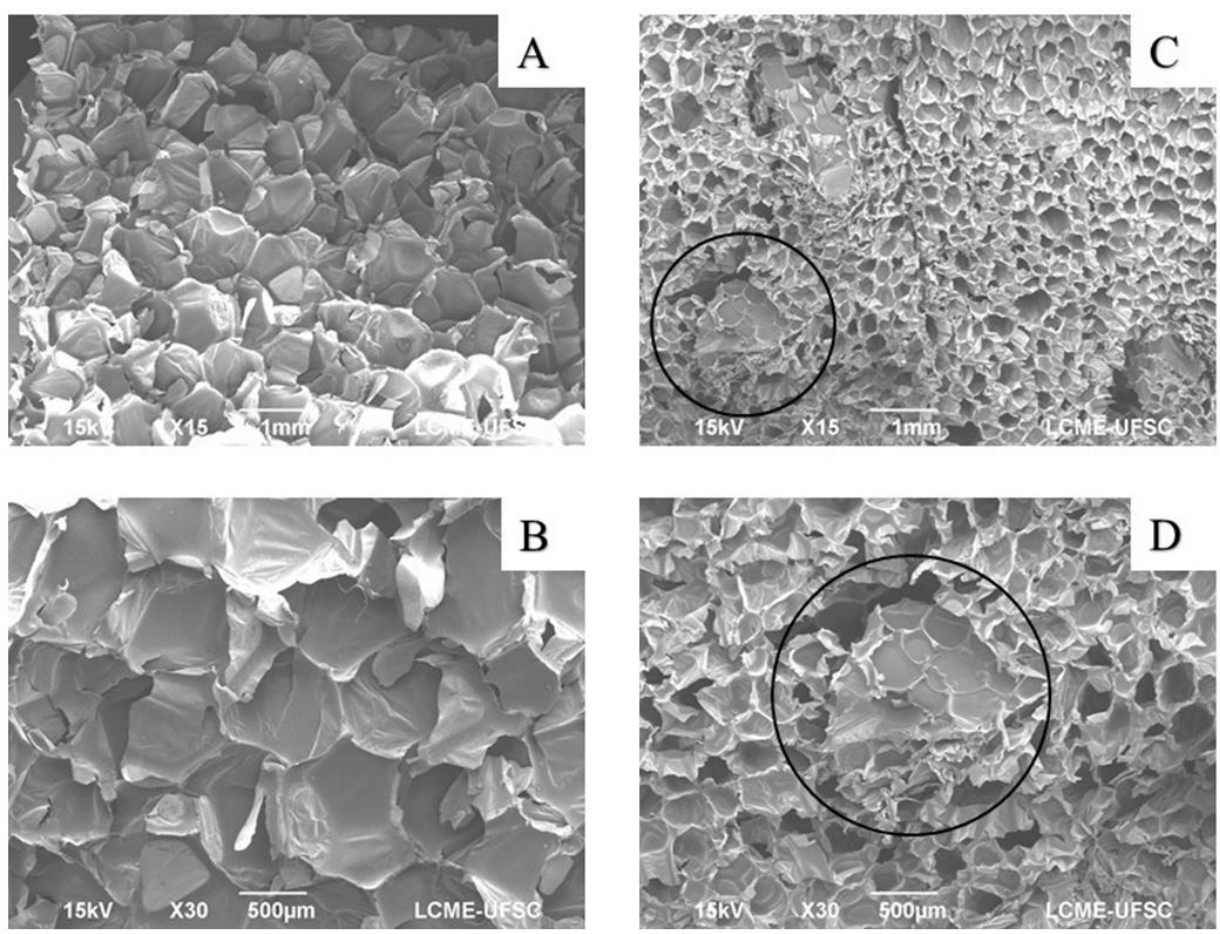

Figure 5. SEM micrographs of freeze-fractured surfaces of PU (A and B) and PU with 20\% conduit residue (C and D), at 15-fold (A and C) and 30-fold magnification (B and D), respectively.

\subsection{Water Resistance Test}

This test was intended to determine the percentage of water absorbed by the material when subjected to immersion. After weighing each specimen, water absorption percentage was obtained for each composite in the different conduit percentages, as shown in Table 2.

Considering that PU and composites presented predominantly closed-cell structures, as shown in the microstructure analysis, there was no significant variation in water absorption between the samples. Most study samples showed about $13 \%$ water absorption in the immersion test. Then, when hold in environmental condition, they lost the absorbed water and returned to the original mass within 6 days, thereby not accumulating moisture. These results indicate that the material keeps its integrity even in contact with water ${ }^{[5,6]}$.

\subsection{Thermal insulation}

Figure 6 shows the results of the mass heating curve of water thermally isolated in PU and PU/PVC composites.

Figure 6 shows that all samples had the same thermal behavior, i.e., the incorporation of PVC residues did not alter the profile of the heating curve already shown by the PU apparatus. The temperature change rate for the mass of water was approximately $0.18^{\circ} \mathrm{C} / \mathrm{min}$ for all samples in Figure 6 . Therefore, the incorporation of conduit residues in the percentage indicated in this study did not hamper the product's performance related to thermal insulation as already shown by PU.
Table 2. Average immersion test results for PU and PU-conduit composites (PU/PVC).

\begin{tabular}{cc}
\hline Sample & $\begin{array}{c}\text { Water absorption percentage } \\
(\%)\end{array}$ \\
\hline $\mathrm{PU}$ & $13.12(0.18)$ \\
$\mathrm{PU} / 5 \mathrm{PVC}$ & $11.86(0.22)$ \\
$\mathrm{PU} / 10 \mathrm{PVC}$ & $13.31(0.17)$ \\
$\mathrm{PU} / 15 \mathrm{PVC}$ & $13.27(0.18)$ \\
$\mathrm{PU} / 20 \mathrm{PVC}$ & $13.71(0.19)$ \\
\hline
\end{tabular}

( ) standard deviation

These results confirm those from the microstructural analysis that identified the existence of closed-cell structures in the composites ${ }^{[3,4,27,28,31,49]}$. The existence of closed cells in the composite is particularly important for materials to be used as thermal insulation, given that conductivity occurs by radiation, which is hampered regardless of the cellular size ${ }^{[20]}$. These facts may explain the similar scores found for the heating curves of thermal-insulated water mass.

\subsection{Mechanical compressive strength}

The effect of PVC on the compressive strength of the PU/PVC composites was studied. Figure 7 shows the compressive strength-deformation profile for the specimens of PU and PU/PVC composites.

The composites studied had an increase in the elasticity modulus and maximum strength as compared to the PU matrix. These behaviors are due to the optimal level of compatibility reached between the components, which indicates that PVC 


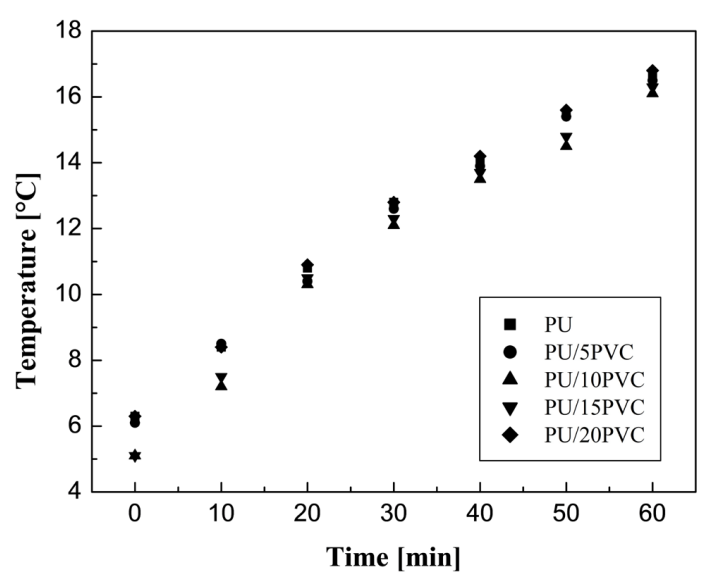

Figure 6. Profile of temperature variations of $\mathrm{PU} / \mathrm{PVC}$ composites with $5 \%, 10 \%, 15 \%$, and $20 \%$ conduit and pure PU.

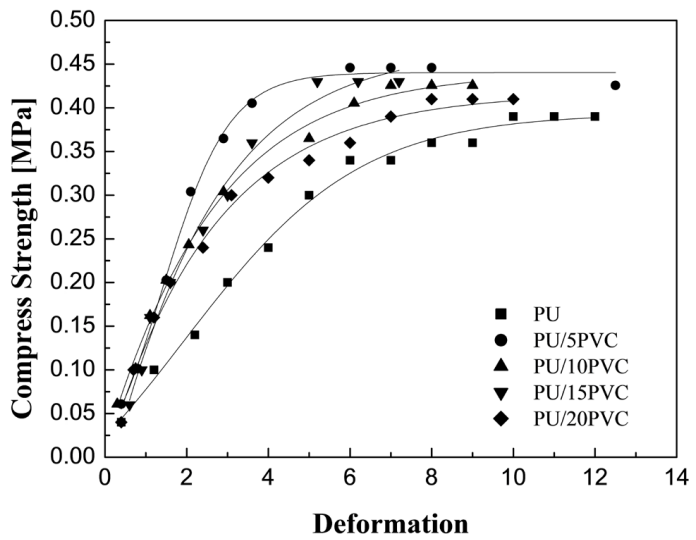

Figure 7. Compressive strength-deformation profile for the specimens of PU/PVC composites.

has contributed to the mechanical reinforcement of PU/PVC composites, because PVC presented a uniform distribution in the PU matrix, as well as good interfacial interaction between the polymers ${ }^{[31,49]}$. The addition of PVC to the PU matrix causes two opposite intermolecular effects. Firstly, it reduces hydrogen interactions in the PU matrix, leading to a reduction in the mechanical properties of the material. Secondly, the intermolecular interactions between the $\mathrm{Cl}$ groups (PVC) and $\mathrm{NH}$ groups (PU) led to an increase in the mechanical properties. The second effect prevailed, leading to a slight increase in the mechanical properties of the material. These results confirm what was observed in microscopy studies, since it shows good adhesion between the PVC and the PU matrix.

It is worth mentioning that the strength-deformation curves for the composites showed elastic and plastic characteristics regardless of the conduit percentage added to the PU matrix. The elastic and plastic deformations are attributed to the presence of polyurethane, wherein PU/PVC composites were less elastic and had higher maximum strength scores as compared to those of PU.
As it can be seen in Figure 7, the material is elastic in the initial stage of load application. This feature is important because the composite with elastic characteristics makes it difficult for the membrane of closed cells to break, which is vital for thermal insulation. Otherwise, air expansion within cell structures, for example, could facilitate thermal radiation $^{[20]}$.

\subsection{Differential Scanning Calorimetry (DSC)}

Figure 8 shows the thermograms obtained for PU plate and PU/PVC composite with $15 \%$ conduit residue. The curves for all blends show similar profile.

$\mathrm{Tg}$ and $\mathrm{Tm}$ scores were similar for both PU plate and PU/PVC composite. For the PU, $\mathrm{Tg}$ was observed at $-9.89^{\circ} \mathrm{C}$ and $\mathrm{Tm}$ at $104.43{ }^{\circ} \mathrm{C}$. $\mathrm{Tg}$ and $\mathrm{Tm}$ scores of the PU/PVC blend were similar to the PU component alone, since the interaction occurs at the interfacial level.

\subsection{Thermogravimetry}

Figure 9 shows the TGA results for PU, PVC and PU/20PVC composite developed in this study. Degradation curves occurred in all samples at a temperature range between $20{ }^{\circ} \mathrm{C}$ and $900{ }^{\circ} \mathrm{C}$. The heating rate was $10{ }^{\circ} \mathrm{C} / \mathrm{min}$ with nitrogen atmosphere.

For the PU sample, mass loss began at $293.40{ }^{\circ} \mathrm{C}$. At $325.00{ }^{\circ} \mathrm{C}$, the mass loss was $45.43 \%$, and complete degradation occurred at $770{ }^{\circ} \mathrm{C}$. The first and second PU decomposition steps correspond to urethane bond-breaking and polyol decomposition, respectively ${ }^{[8,39,50,51]}$.

Dehydrochlorination of PVC starts at the temperature the $32.87^{\circ} \mathrm{C}, \mathrm{HCl}$ is released from the polymer backbone in sequential stages, to yield long, conjugated polyenes. At the temperature of $52.31{ }^{\circ} \mathrm{C}$, there was a PVC mass loss of $57.68 \%$, and at a temperature of $208.13^{\circ} \mathrm{C}$, mass loss was $87.49 \% \%^{[33,35,39]}$, completing the decomposition around $300^{\circ} \mathrm{C}$.

For the PU/PVC composite with $20 \%$ conduit residue, degradation also occurred in two stages. The degradation started at $22.5{ }^{\circ} \mathrm{C}$ and then a decrease in the values of degradation temperatures occurred, which can be attributed to the PU/PVC interface. Dehydrochlorination occurred mainly in the first stage of degradation and began at a lower temperature than that observed for $\mathrm{PVC}$. $\mathrm{HCl}$ formation may have been catalyzed by PU amino groups ${ }^{[3,35,39,50]}$. At a temperature of $48.39^{\circ} \mathrm{C}$, there was a $51.39 \%$ loss of the total mass of the sample, which means that urethane bond-breaking also occurred at a lower temperature than that observed for the PU. There were two effects on the temperature scores for the composite degradation. The first effect consisted of the partial destruction of PU hydrogen bonds caused by the addition of PVC in the PU matrix. Thus, the temperature score for the PU degradation decreases by increasing the PVC content. The second effect is that the increase in the PVC content causes greater interaction between the $\mathrm{Cl}$ groups and $\mathrm{NH}$ groups, leading to catalyze $\mathrm{C}-\mathrm{Cl}$ and $\mathrm{C}-\mathrm{NH}$ bond breaking at lower temperatures. The results indicate that these effects led to decrease the degradation scores for the PU/PVC composite. Degradation of the composite samples was completed at $300{ }^{\circ} \mathrm{C}$, whereas for the PU it occurred at $770{ }^{\circ} \mathrm{C}$. 


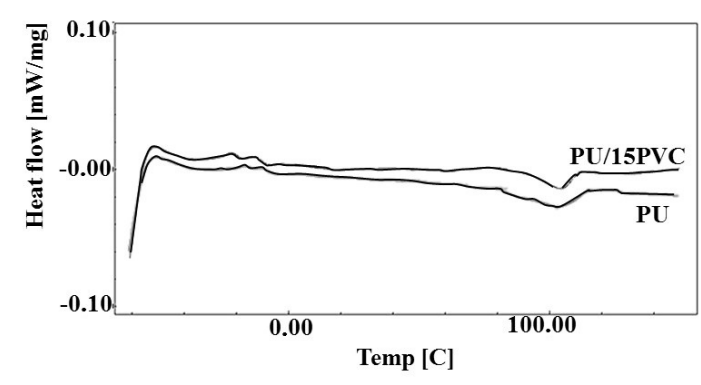

Figure 8. DSC thermogram for PU plate and PU/PVC composite with $15 \%$ conduit residue.

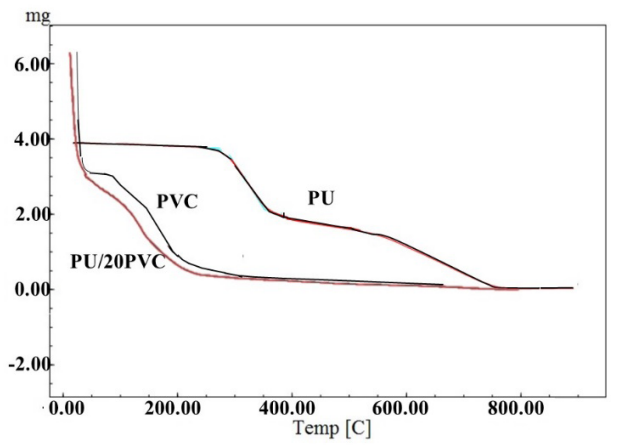

Figure 9. TGA spectrum for PU, PVC and PU/PVC composite with $20 \%$ conduit residue.
The interaction between polymers can influence the ignition and burning rate of the materials, given that $\mathrm{HCl}$ formation at a temperature lower than that of the PU decomposition act as a retardant in the gaseous phase of the composite burning. For that purpose, a vertical burning rate test was performed, which is designed for a diagnosis of real burning conditions.

\subsection{Burning rate}

The composites under study were assessed according to the NBR 9178:2015 ${ }^{[48]}$ that regulates flexible polyurethane foam testing to determine burning characteristics and investigate the effect of conduit residue incorporation into the PU matrix. According to the NBR 9178:2015 ${ }^{[48]}$ and ASTM D3801 ${ }^{[54]}$, by comparing the burning times of the two composites it is possible to estimate burning speed and burning length, i.e., the distance traveled by the flame along the board.

Figure 10 exhibits a sequence of images (A-F) for the PU/20PVC composite burning, where (A) $2 \mathrm{~s}$, (B) $4 \mathrm{~s}$, (C) $5 \mathrm{~s}$, (D) $6 \mathrm{~s}$ and (F) $7 \mathrm{~s}$ from the start of the burn.

In the burning test for PU plate, ignition was followed by self-sustained combustion, with complete burning of the specimen in $7 \mathrm{~s}$, that is, the burning rate was $50.9 \mathrm{~mm} / \mathrm{s}^{[13,54,55]}$. Figure 10 (A-F) exhibits the PU/20PVC composite burning test; the other samples showed similar behavior to the $\mathrm{PU} / 20 \mathrm{PVC}$. There was immediate ignition and complete burning of the specimens in the time range between $3 \mathrm{~s}$ and $8 \mathrm{~s}$; thus, the burning rate ranged from 44.5 to $118.7 \mathrm{~mm} / \mathrm{s}^{[56]}$.
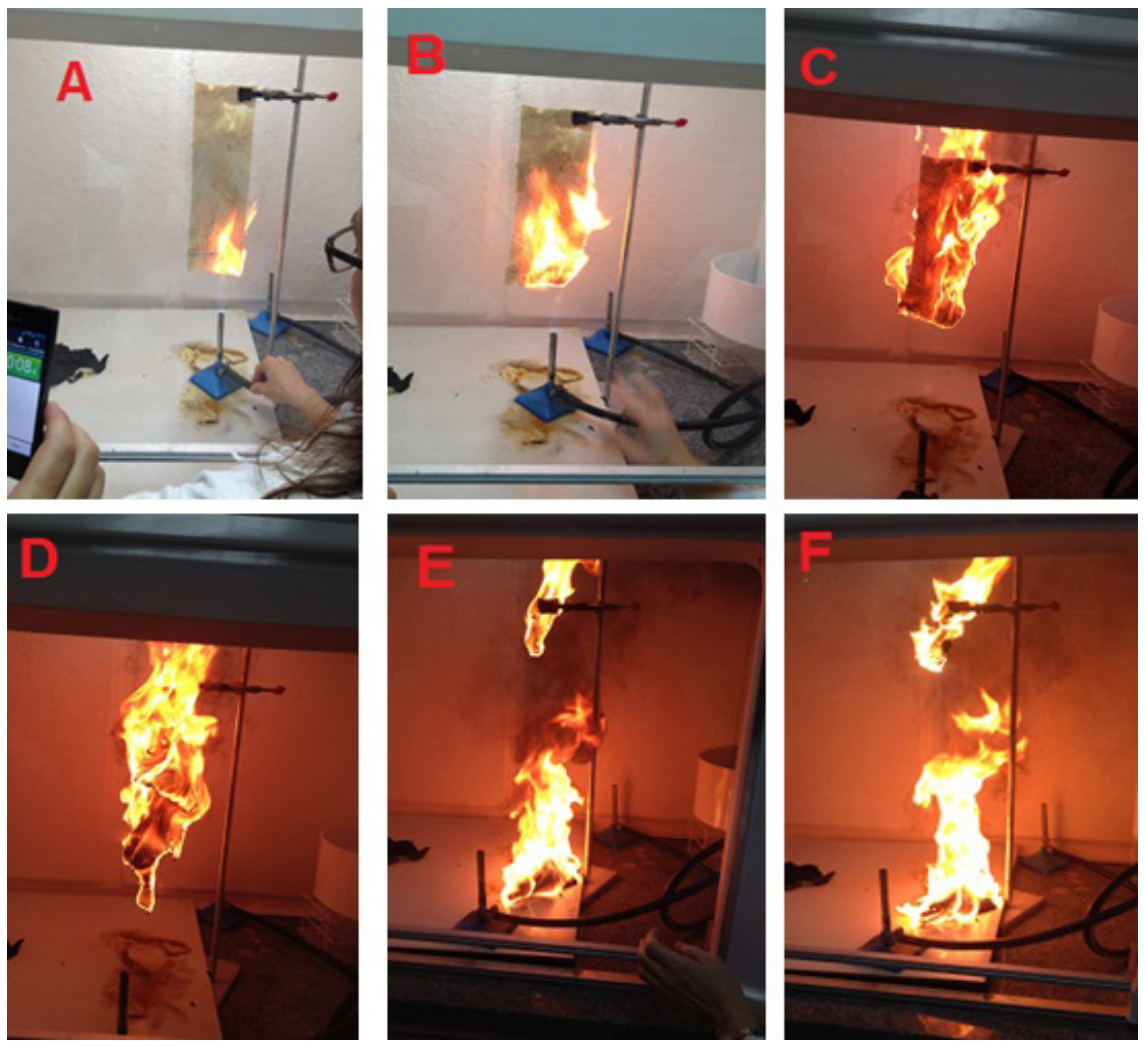

Figure 10. Burning test for the PU/20PVC composite, where (A) $2 \mathrm{~s}$, (B) $4 \mathrm{~s}$, (C) $5 \mathrm{~s}$, (D) $6 \mathrm{~s}$ and (F) $7 \mathrm{~s}$ from the start of the burn. 
The presence of PVC in the composite did not slow the burning rate.

According Vilar ${ }^{[57]}$, when polyurethane foam is burned in the open air, a complete combustion occurs, forming carbon dioxide $\left(\mathrm{CO}_{2}\right)$, nitrogen oxides $(\mathrm{NOx})$, and water $\left(\mathrm{H}_{2} \mathrm{O}\right)$. However, in a closed environment, such as in buildings, the effect of burning becomes even more dangerous because of the drop in atmospheric oxygen, which leads to an incomplete combustion and creates poisonous carbon monoxide (CO), in addition to producing hydrogen cyanide ( $\mathrm{HCN})$, also known as hydrocyanic acid or cyanide gas $^{[26,58]}$.

It is widely accepted that PVC dehydrochlorination involves a gradual reaction between chlorine and hydrogen atom neighbors in the polymer chain, comprising a double bond between the carbon atoms in positions in which the two atoms were originally connected, forming a structure of allylic chlorine with another chlorine atom of the polymer chain $^{[11,33,35,39]}$. Complete combustion leads to the formation of hydrochloric acid, carbon dioxide and water.

The addition of PVC residues to polyurethane does not act as a flame retardant on the composite. Therefore, to meet the requirements of the NBR 9178:2015 ${ }^{[48]}$, a flame-retardant additive should be included in the formulation ${ }^{[11,51]}$.

According to the NBR 9178:2015 ${ }^{[48]}$, flame-retardant additives must be added to coatings, such as polyurethane, for greater security of the environment and emergency evacuation. The use of polyurethane in the construction industry is regulated by national norms, such as ABNT NBR 9178:2015 ${ }^{[48]}$, ABNT NBR ISO 15366-2:2006 ${ }^{[59]}$, ABNT NBR ISO 31000:2009 ${ }^{[60]}$, ABNT NBR ISO 14001:2004 ${ }^{[61]}$, and by international regulations, among which the Polyurethane Products in Fires: Acute Toxicity of Smoke and Fire Gases ${ }^{[62]}$, Fire Safety Guidance: Working with Polyurethane Foam Products During New Construction Retrofit and Repair (AX-426) ${ }^{[63]}$ and Model Building Code Fire Performance Requirements $(\mathrm{AX}-265)^{[64]}$.

\section{Conclusions}

This work presented an alternative to the use of conduit residue from the construction industry to produce a new material for thermal insulation. The composites were prepared by simple mixture in polyol and then polymerized, leading to materials that had thermal insulation behavior similar to that of PU. SEM images of the material exhibited a closed-cell structure, which revealed the thermal insulation property exhibited by the composites and explained water absorption with little variation between the samples. The composites presented elastic and plastic characteristics regardless of the percentage of conduit residues added to the PU matrix, but with enough mechanical strength to be used as thermal insulation. In the DSC thermograms, PU characteristics were predominant, whereas the $\mathrm{Tg}$ and $\mathrm{Tm}$ scores were similar for the PU/PVC composites. Findings from this study revealed that the addition of PVC (conduit) residues to polyurethane did not provide flame retardant properties to the composites as assessed by NBR 9178: 2015. Therefore, a flame-retardant additive must be included in the formulation to meet the requirements of the NBR 9178: $2015^{[48]}$.

\section{Acknowledgements}

The authors wish to thank UNISUL for the financial and technical support to carry out this work. This work was awarded a scholarship from the Support Fund for Maintenance and Development of Higher Education (FUMDES) of Santa Catarina, Brazil, with funds provided under Article 171 of the State Constitution.

\section{References}

1. Wang, S., Chen, H., \& Zhang, L. (2014). Thermal decomposition kinetics of rigid polyurethane foam and ignition risk by a hot particle. Journal of Applied Polymer Science, 131(4), 3935939368. http://dx.doi.org/10.1002/app.39359.

2. Mancini, S. D., Darbello, S. M., Schwartzman, J. A. S., Kagohara, D. A., Nogueira, A. R., Keiroglo, R. C., Franco, C. S., Mantovani, V. A., \& Wiebeck, H. (2007). Caracterização dos Resíduos da Construção Civil de Sorocaba-SP com Ênfase em Plásticos. In Anais do $9^{\circ}$ Congresso Brasileiro de Polímeros (pp. 1-9). Campina Grande: IPEN.

3. Zhang, X.-L., Duan, H.-J., Yan, D.-X., Kang, L.-Q., Zhang, W.-Q., Tang, J.-H., \& Li, Z.-M. (2015). A facile strategy to fabricate microencapsulated expandable graphite as a flameretardant for rigid polyurethane foams. Journal of Applied Polymer Science, 42364, 1-9. http://dx.doi.org/10.1002/ app.42364.

4. Xi, W., Qian, L., Chen, Y., Wang, J., \& Liu, X. (2015). Addition flame-retardante behaviors of expandable graphite and [bis(2hydroxyethyl)amino]-methyl-phosphonic acid dimethyl ester in rigid polyurethane foams. Polymer Degradation \& Stability, 122, 36-43. http://dx.doi.org/10.1016/j.polymdegradstab.2015.10.013.

5. Pellizzi, E., Lattuati-Derieux, A., Lavédrine, B., \& Cheradame, H. (2014). Degradation of polyurethane ester foam artifacts: chemical properties, mechanical properties and comparison between accelerated and natural degradation. Polymer Degradation \& Stability, 107, 255-261. http://dx.doi.org/10.1016/j. polymdegradstab.2013.12.018.

6. Jakubowicz, I., Yarahmadi, N., \& Gevert, T. (1999). Effects of accelerated and natural ageing on plasticized polyvinyl chloride (PVC). Polymer Degradation \& Stability, 66(3), 415-421. http://dx.doi.org/10.1016/S0141-3910(99)00094-4.

7. Toldy, A., Harakály, G., Szolnoki, B., Zimonyi, E., \& Marosi, G. (2012). Flame retardancy of thermoplastics polyurethanes. Polymer Degradation \& Stability, 97(12), 2524-2530. http:// dx.doi.org/10.1016/j.polymdegradstab.2012.07.015.

8. Singh, H., \& Jain, A. K. (2008). Ignition, combustion, toxicity, and fire retardancy of polyurethane foams: a comprehensive review. Journal of Applied Polymer Science, 111, 1115-1143. http://dx.doi.org/10.1002/app.29131.

9. Resolução CONAMA n ${ }^{\circ} 307$, de 5 de julho de 2002. (2002, 17 july). Estabelece diretrizes, critérios e procedimentos para a gestão dos resíduos da construção civil. Diário Oficial da República Federativa do Brasil, Brasília. Retrieved in 13 May 2016, from http://www.mma.gov.br/port/conama/

10. Associação Brasileira de Normas Técnicas - ABNT. (2008). ABNT NBR 15465: requisitos de desempenho para sistemas de eletrodutos plásticos para instalações elétricas de baixa tensão. Rio de Janeiro: ABNT.

11. Starnes, W. H., Jr., \& Ge, X. (2004). Mechanism of Autocatalysis in the Thermal Dehydrochlorination of Poly(vinyl chloride). Macromolecules, 37(2), 352-359. http://dx.doi.org/10.1021/ ma0352835.

12. Wypych, J. (1985). Polyvinyl chloride degradation. In A. D. Jenkins (Ed). Polymer Science Library 3. Amsterdam: Elsevier Science Publishers. 
13. Guo, H., Gao, Q., Ouyang, C., Zheng, K., \& Xu, W. (2015). Research on properties of rigid polyurethane foam with heteroaromatic and brominated benzyl polyols. Journal of Applied Polymer Science, 132(33), 423-449. http://dx.doi. org/10.1002/app.42349.

14. Cangemi, J. M., Santos, A. M., \& Claro, N. S. (2009). Poliuretano: de travesseiros a preservativos, um polímero versátil. Química Nova na Escola, 31(3), 159-164. Retrieved in 13 May 2016, from http://qnesc.sbq.org.br/online/qnesc31_3/02-QS-3608. pdf

15. Thirumal, M., Khastgir, D., Manjunath, B. S., Naik, Y. P., \& Singla, N. K. (2007). Mechanical, morphological and thermal properties of rigid polyurethane foam: effect of the fillers. Cellular Polymers, 26(4), 245-259.

16. Laoutid, F., Bonnaud, L., Alexandre, M., Lopez-Cuesta, J.M., \& Dubois, P. (2009). New prospects in flame retardant polymer materials: From fundamentals to nanocomposites. Materials Science and Engineering, 63(3), 100-125. http:// dx.doi.org/10.1016/j.mser.2008.09.002.

17. Wicksa, D. A., \& Wicks, Z. W., Jr. (2001). Blocked isocyanates III Part B: uses and applications of blocked isocyanates. Progress in Organic Coatings, 41, 1-83.

18. Awad, H., Gül, M., Zaman, H., Yu, H., \& Al-Hussein, M. (2014). Evaluation of the thermal and structural performance of potential energy efficient wall systems for mid-rise woodframe buildings. Energy and Building, 82, 416-427. http:// dx.doi.org/10.1016/j.enbuild.2014.07.032.

19. Gu, R., Sain, M. M., \& Konar, S. K. (2013). A feasibility study of polyurethane composite foam with added hardwood pulp. Industrial Crops and Products, 42, 273-279. http://dx.doi. org/10.1016/j.indcrop.2012.06.006.

20. Zhang, G., Wang, B., Ma, L., Wu, L., Pan, S., \& Yang, J. (2014). Energy absorption and low velocity impact response of polyurethane foam filled pyramidal lattice core sandwich panels. Composite Structures, 108, 304-310. http://dx.doi. org/10.1016/j.compstruct.2013.09.040.

21. Garrido, M., Correia, J. R., \& Keller, T. (2016). Effect of service temperature on the shear creep response of rigid polyurethane foam used in composite sandwich floor panels. Construction \& Building Materials, 18, 235-244. http://dx.doi.org/10.1016/j. conbuildmat.2016.05.074.

22. Hadden, R., Alkatib, A., Rein, G., \& Torero, J. L. (2014). Radiant ignition of polyurethane foam: the effect of sample size. Fire Technology, 50(3), 673-691. http://dx.doi.org/10.1007/ s10694-012-0257-x.

23. Gallo, J. B. E., \& Agnelli, J. A. M. (1998). Aspectos do comportamento de polímeros em condições de incêndio. Polimeros: Ciência e Tecnologia, 8(1), 23-37. http://dx.doi. org/10.1590/S0104-14281998000100005.

24. Qian, L., Feng, F., \& Tang, S. (2014). Bi-phase flame-retardant effect of hexa-phenoxy-cyclotriphosphazene on rigid polyurethane foams containing expandable graphite. Polymer, 55(1), 95-101. http://dx.doi.org/10.1016/j.polymer.2013.12.015.

25. Eljarrat, E., \& Barceló, D. (2011). Brominated flame retardants. Berlin: Springer.

26. Bayler, C. L., \& Hirschler, M. M. (2008). Thermal decomposition of polymers, the SFPE Handbook of Fire Protection Engineering (4th ed.). Quincy: National Fire Protection Association.

27. Tsuyumoto, I., Onoda, Y., Hashizume, F., \& Kinpara, E. (2011). Flame-Retardant Rigid Polyurethane Foams Prepared with Amorphous Sodium Polyborate. Journal of Applied Polymer Science, 122(3), 1707-1711. http://dx.doi.org/10.1002/app.34025.

28. Thirumal, M., Khastgir, D., Singha, N. K., Manjunath, B. S., \& Naik, Y. P. (2010). Halogen-free flame-retardant rigid polyurethane foams: Effect of alumina trihydrate and triphenylphosphate on the properties of polyurethane foams.
Journal of Applied Polymer Science, 116(4), 2260-2268. http:// dx.doi.org/10.1002/app.31626.

29. Albuquerque, I. M., Pasqualoto, A. S., Trevisan, M. E., Gonçalves, M. P., Badaró, A. F. V., Moraes, J. P., \& Prado, A. L. C. (2013). Role of physiotherapy in the rehabilitation of survivors of the Kiss nightclub tragedy in Santa Maria, Brazil. Physiotherapy, 99(4), 269-270. PMid:24050497. http://dx.doi. org/10.1016/j.physio.2013.07.001.

30. Abd El-Wahab, H., Abd El-Fattah, M., Abd El-Khalik, N., \& Kazlauciunas, A. (2015). Synthesis and performance of new modified reactive flame-retardant alkyd resin based on tetrabromophthalic anhydride as varnish for surface coatings. Journal of Coatings Technology and Research, 12(1), 97-105. http://dx.doi.org/10.1007/s11998-014-9615-6.

31. Li, M., Luo, J., Huang, Y., Li, X., Yu, T., \& Ge, M. (2014). Recycling of Waste Poly(ethylene terephthalate) into flameretardant rigid polyurethane foams. Journal of Applied Polymer Science, 131(40857), 1-6.

32. Hezma, A. M., Elashmawi, I. S., Rajeh, A., \& Kamal, M. (2016). Change spectroscopic, thermal and mechanical studies of PU/PVC blends. Physica B: Condensed Matter, 495, 4-10. http://dx.doi.org/10.1016/j.physb.2016.04.043.

33. Guo-Dong, F., Yun, H., Pu-You, J., Ma, Y., \& Yong-Hong, Z. (2015). Influence of a nitrogen-containing oil-based plasticizer on mechanical, thermal stability and fire performance of plasticized poly(vinyl chloride) and study of its mechanism of flame retardancy with Py-GC/MS. Industrial Crops and Products, 77, 883-894. http://dx.doi.org/10.1016/j.indcrop.2015.09.032.

34. Radhakrishnan Nair, M. N., \& Gopinathan Nair, M. R. (2012). Studies on impact modification and fractography of solution cast blends of PVC and NR/PU block copolymers. Polymer Bulletin, 68(3), 859-877. http://dx.doi.org/10.1007/s00289011-0656-z.

35. Chen, C.-J., Tseng, I.-H., Lu, H.-T., Tseng, W.-Y., Tsai, M.H., \& Huang, S.-L. (2011). Thermal and tensile properties of HTPB-based PU with PVC blends. Materials Science and Engineering A, 528(15), 4917-4923. http://dx.doi.org/10.1016/j. msea.2011.03.056.

36. Radhakrishnan Nair, M. N., \& Gopinathan Nair, M. R. (2011). Thermogravimetric analysis of PVC/NR-b-PU blends. Journal of Thermal Analysis and Calorimetry, 103(3), 863-873. http:// dx.doi.org/10.1007/s10973-010-1113-1.

37. HighBeam. (2010). Dow Automotive Systems introduces advanced PU foam technology in Europe: broad proprietary R\&D capabilities for aging stability, low emissions and PVC skin compatibility. Cellular Polymers, 29(2), 143.

38. Radhakrishnan Nair, M. N., \& Gopinathan Nair, M. R. (2006). Compatibility studies and characterisation of a PVC/NR blend system using NR/PU block copolymer. Polymer Bulletin, 56(6), 619-631. http://dx.doi.org/10.1007/s00289-006-0524-4.

39. Grigoryeva, O., Fainleib, A., Stepanenko, L., Sergeeva, L., $\&$ Pissis, P. (2005). Recycling of PVC/PU waste and reuse in PVC formulations: structure-property relationship. Polymer Engineering and Science, 45(6), 801-808. http://dx.doi. org/10.1002/pen.20343.

40. Al-Salah, H. A. (1998). Polymer compatibility enhancement via ion-ion and ion-dipole interactions: Ternary blends of polyurethane, poly(vinyl chloride) and poly(styrene-co-maleic anhydride). Polymer Bulletin, 40(4), 477-484. http://dx.doi. org/10.1007/s002890050279.

41. Mariappan, T., Yi, D., Chakraborty, A., Singha, N. K., \& Wilkie, C. A. (2014). Thermal stability and fire retardancy of polyurea and epoxy nanocomposites using organically modified magadiite. Journal of Fire Sciences, 32(4), 346-361. http://dx.doi.org/10.1177/0734904113516268. 
42. Peng, Y.-H., Shih, Y.-H., Lai, Y.-C., Liu, Y.-Z., Liu, Y.-T., \& Lin, N.-C. (2014). Degradation of polyurethane by bacterium isolated from soil and assessment of polyurethanolytic activity of a Pseudomonas putida strain. Environmental Science and Pollution Research International, 21(16), 9529-9537. PMid:24633845. http://dx.doi.org/10.1007/s11356-014-2647-8.

43. Mano, E. B., \& Mendes, L. C. (2004). Introdução a Polímeros. São Paulo: Edgar Blücher.

44. Trovati, G., Sanches, E. A., Claro, S., No., Mascarenhas, Y. P., \& Chierice, G. O. (2010). Characterization of Polyurethane Resins by FTIR, TGA, and XRD. Journal of Applied Polymer Science, 115(1), 263-268. http://dx.doi.org/10.1002/app.31096.

45. American Society for Testing and Materials-ASTM. (2010). ASTM D570-98(2010)e1: standard test method for water absorption of plastics. West Conshohocken: ASTM.

46. Tudo Sobre Plasticos. (2016). Retrieved in 13 May 2016, from http://www.tudosobreplasticos.com/aditivos/antichamas.asp

47. American Society for Testing and Materials -ASTM. (2015). ASTM D695 -15: standard test method for compressive properties of rigid plastics. West Conshohocken: ASTM. http://dx.doi. org/10.1520/d0695-15.

48. Associação Brasileira de Normas Técnicas - ABNT. (2015). ABNT NBR 9178: espuma flexivel de poliuretano: determinação das características de queima. Rio de Janeiro: ABNT.

49. Wu, D.-H., Zhao, P.-H., Liu, Y.-Q., Liu, X.-Y., \& Wang, X.-F. (2013). Halogen free flame retardant rigid polyurethane foam with a novel phosphorus2nitrogen intumescent flame retardant. Journal of Applied Polymer Science, 131(11), 1-7.

50. Chattopadhyay, D. K., \& Webster, D. C. (2009). Thermal stability and flame retardancy of polyurethanes. Progress in Polymer Science, 34(10), 1068-1133. http://dx.doi.org/10.1016/j. progpolymsci.2009.06.002.

51. Lopes, M. C., Trigueiro, J. P. C., Castro, V. G., Lavall, R. L., \& Silva, G. G. (2016). Otimização do processo de dispersão de nanotubos de carbono em poliuretano termorrígido. Polímeros: Ciência e Tecnologia, 26(1), 81-91. http://dx.doi. org/10.1590/0104-1428.2087.

52. Furlan, L. G., Duarte, U. L., \& Mauler, R. S. (2012). Avaliação das propriedades de compósitos de polipropileno reforçados com casca de aveia. Química Nova, 35(8), 1499-1501. http:// dx.doi.org/10.1590/S0100-40422012000800002.

53. Salmoria, G. V., Leite, J. L., Vieira, L. F., Pires, A. T. N., \& Roesler, C. R. M. (2012). Mechanical properties of PA6/ PA12 blend specimens prepared by selective laser sintering. Polymer Testing, 31(3), 411-416. http://dx.doi.org/10.1016/j. polymertesting.2011.12.006.

54. American Society for Testing and Materials-ASTM. (2010). ASTM D3801-10: standard test method for measuring the comparative burning characteristics of solid plastics in a vertical position. West Conshohocken: ASTM.

55. Xu, Y., Tang, M., Chen, X., Chen, M., Yu, J., Ma, Y., Sun, Z., Zhang, Z., \& Lv, J. (2015). Effect of phosphorus masterbatch on flame retardancy and thermal stability of polypropylene/ thermoplastic polyurethane blends. Polymers \& Polymer Composites, 23(2), 113-119.

56. American Chemistry Council. (2016, March 11). Polyurethanes. Retrieved in 13 May 2016, from http://polyurethane. americanchemistry.com/Health-Safety-and-Product-Stewardship

57. Vilar, W. D. (2004). Química e tecnologia dos poliuretanos. Rio de Janeiro: Reagentes \& Fundamentos. Retrieved in 13 May 2016, from http://www.poliuretanos.com.br/ Cap1/11mercado. $\mathrm{htm}$

58. Wang, J.-S., Wang, G.-H., Liu, Y., Jiao, Y.-H., \& Liu, D. (2014). Thermal stability, combustion behavior, and toxic gases in fire effluents of an intumescent flame-retarded polypropylene system. Industrial \& Engineering Chemistry Research, 53(17), 6978-6984. http://dx.doi.org/10.1021/ie500262w.

59. Associação Brasileira de Normas Técnicas - ABNT. (2006). ABNT NBR 15366-2: painéis industrializados com espuma rígida de poliuretano. Parte 2: classificação quanto à reação ao fogo. Rio de Janeiro: ABNT.

60. Associação Brasileira de Normas Técnicas - ABNT. (2009). NBR ISO 31000: gestão de riscos: princípios e diretrizes. Rio de Janeiro: ABNT.

61. Associação Brasileira de Normas Técnicas - ABNT. (2004). ABNT NBR ISO 14001: sistemas de gestão ambiental: requisitos com orientações para uso. Rio de Janeiro: ABNT.

62. Landry, T. D., Pauluhn, J., Daems, D., \& Reimann, K. A. (2002). Polyurethane products in fires: acute toxicity of smoke and fire gases. Retrieved in 13 May 2016, from http://polyurethane. americanchemistry.com/Resources-and-Document-Library/ Polyurethane-Products-in-Fires-Acute-Toxicity-of-Smokeand-Fire-Gases.pdf

63. American Chemistry Council. (2011). Fire safety guidance.. working with polyurethane foam products during new construction, retrofit and repair (AX-426). Washington. Retrieved in 13 May 2016, from http://polyurethane.americanchemistry.com/ Resources-and-Document-Library/11365.pdf

64. American Chemistry Council. (2012, March 11). Model Building Code Fire Performance Requirements (AX-265). Washington. Retrieved in 13 May 2016, from https://polyurethane. americanchemistry.com/Resources-and-Document-Library/11361. pdf

Received: May 19, 2016

Revised: Sept. 13, 2016

Accepted: Sept. 16, 2016 